\title{
İletişimsizliğin Gülen Yüzleri: Karagöz ile Hacivat
}

\section{Dr. Yıldız Yenen Avcı ${ }^{1 *}$}

Geliş tarihi: 23.05.2020

Kabul tarihi: 17.06.2020

\section{Atıf bilgisi: \\ IBAD Sosyal Bilimler Dergisi \\ Sayı: $8 \quad$ Sayfa: $295-307$ \\ Yıl: 2020 Dönem: Güz}

This article was checked by Turnitin. Similarity Index $22 \%$

Bu makalede araştırma ve yayın etiğine uyulmuştur.

${ }^{1}$ MEB, Türkiye, y_yenen@hotmail.com ORCID ID 0000-0001-8697-5375

\footnotetext{
* Sorumlu Yazar
}

$\ddot{O} \mathbf{Z}$

Geleneksel Türk tiyatrosunun önemli türlerinden olan gölge oyunu, toplumu ilgilendiren konuları kuklalar aracılığıyla beyaz perdeye yansitan bir eğlence ve eğitim aracıdır. $\mathrm{Bu}$ araştırmada Türkçe ders kitaplarında yer alan Karagöz ile Hacivat metinlerinin iletişim boyutuyla ele alınması ve bu metinlerde yer alan mizah unsurlarının tespit edilmesi amaçlanmıștır. Çalıșma doküman incelemesi modelindedir. Araştırmanın verileri, 2018-2019 Eğitim-Öğretim Yılı içinde Ortaokul ve İmam Hatip Ortaokulunda okutulması ön görülen Türkçe ders kitaplarından elde edilmiştir. Araştırma sonucunda; ders kitaplarının \%86'sında Karagöz metinlerine yer verildiği, bu metinlerin genel olarak tiyatro türünde okuyucuya sunulduğu, metinlerin daha çok "millî kültür" ve "erdemler" teması altında siralandiğ 1 ve dört temel beceriden en az yazma becerisiyle ilişkilendirildiği tespit edilmiştir. İncelenen metinlerde Karagöz'ün söylediği sözlerin, sergilediği davranışların iletişimin önünde güçlü birer engel olmakla birlikte bu engelin, Hacivat'ın sahip olduğu yapıcı özellikler aracılığıyla aşıldığ 1 , iletişimin zor şartlarda bile sürdürülebileceğini gösteren Karagöz-Hacivat metinlerinin okuyucuyu güldüren, eğlendiren birer mizah unsuruna dönüştügü görülmektedir. $\mathrm{Bu}$ bakımdan Karagöz ile Hacivat'ın okuyucuyu yalnızca eğlendirmekle kalmadığı, iletişimsizlik yoluyla iletişim olgusuna dikkat çektiğini ve mizah duygusunun gelişmesine katkıda bulunduğunu söylemek mümkündür.

Anahtar Kelimeler: Türkçe eğitimi, Türkçe ders kitapları, iletişim, Karagöz ile Hacivat, mizah unsurları. 


\section{Smiling Faces of Miscommunication: Karagöz and Hacivat}

\section{Dr. Yıldız Yenen Avcı ${ }^{{ }^{*}}$}

First received: 23.05 .2020

Accepted: 17.06.2020

\section{Citation:}

IBAD Journal of Social Sciences

Issue: $8 \quad$ Pages: 295-307

Year: $2020 \quad$ Session: Fall

This article was checked by Turnitin. Similarity Index 22\%

19EB, Turkey, y_yenen@hotmail.com ORCID ID 0000-0001-8697-5375

\section{* Corresponding Author}

\begin{abstract}
Shadow play, which is one of the important types of traditional Turkish theater, is an entertainment and education tool that reflects the issues that concern the society to the big screen through puppets. In this study, it was aimed to address the texts of Karagöz and Hacivat in the Turkish textbooks with the communication dimension and to identify the humor elements in these texts. The study is in document review model. The data of the research was obtained from the Turkish textbooks, which were foreseen to be taught in the Middle School and Imam Hatip Secondary School in the 2018-2019 academic year. As a result of the research; It was determined that $86 \%$ of the textbooks included Karagöz texts, these texts were presented to the reader in general in the type of theater, the texts were mostly listed under the theme of "national culture" and "virtues" and were associated with the least writing skill of the four basic skills. In the texts examined, it is seen that the words Karagöz speaks and the behaviors exhibited are transformed into humor elements that make the reader laugh and entertain the reader, which means that this obstacle is overcome through the constructive features of Hacivat, and that communication can be maintained even under difficult conditions. In this regard, it is possible to say that Karagöz and Hacivat not only entertain the reader, but also draw attention to the phenomenon of communication through non-communication and contribute to the development of a sense of humor.
\end{abstract}

Keywords: Turkish education, Turkish text books, communication, Karagöz and Hacivat, humor elements. 


\section{GíRiş}

Latince "communicarre" fiilinden türeyen ve başkalarıyla birlikte olma, bilgiyi veya haberi paylaşma, yayma, herkesin yararlanmasını sağlama anlamında kullanılan iletişim sözcüğü, kaynak ile alıcı arasında gerçekleşen bir etkileşim sürecidir (Köknel, 2005, s. 31-47). Kişi kendini anlatabilmek ve karşısındakini anlayabilmek için iletişime ihtiyaç duyar. Reklam panolarından, aile ilişkilerine, özel hayattan iş hayatına kadar iletişim hayatın her alanında kendini gösterir (Cengiz, 2019).

İletişim süreci kaynak (gönderici), alıcı, ileti, kanal, bağlam, kod gibi ögelerle şekillense de bilgi alışverişinin en temel kavramları kaynak, alıcı ve mesajdır. Kaynakla alıcı arasındaki bu bilgi paylaşımı ileti (mesaj) aracılığıyla gerçekleşir. Kaynak, iletisini alıcıya aktarabilmek ve onda etki uyandırabilmek için işaret, şifre, sembol sözcük, resim, jest, mimik gibi çeşitli unsurlardan yararlanır (Köknel, 2005, s. 31-47). Bilgileri karşımızdakine aktarmada kullanılan bu unsurlara bağlı olarak çeşitli iletişim yöntemleri ortaya çıkmıştır. Sözlü iletişim duygu ve düşüncelerin konuşma yoluyla, sözsüz iletişim beden dili, jest ve mimiklerle; yazılı iletişim harf, sayı ve sembollerin kullanılmasıyla, görsel iletişim ise fikir ve bilgilerin fotoğraf, resim, şema, grafikler yoluyla anlatılmasına dayanır (Cengiz, 2019).

İletişimi zaman ve mekâna bağlı olarak yüz yüze ve uzaktan iletişim olarak da ayırmak mümkündür. Yüz yüze iletişimde insanlar aynı mekânı paylaşırken uzaktan iletişimde ise faklı mekânlarda bulunan insanlar teknolojik araçlar aracılığıyla birbirleriyle etkileşimde bulunurlar. İletişim bazen tek yönlü bazen de çift yönlü olabilmektedir. Tek yönlü iletişimde yalnızca kaynaktan hedefe doğru mesaj aktarımı olur, yani hedef pasif durumdadır. Çift yönlü iletişimde ise kaynaktan hedefe olabileceği gibi hedeften de kaynağa mesaj gönderilir. İlişki sistemleri bakımından ise kişi içi iletişim, kişiler arası iletişim, grup içi iletişim ve kitle iletişimi gibi türleri mevcuttur. İç iletişim olarak geçen kişi içi iletişim bireyin kendi iç dünyasıyla olan iletişimini anlatır. Kişinin kendi kendisiyle yaptığ konuşmalar ile iç konuşmaları buna örnektir. İç iletişimde, kaynak, alıcı, mesaj, verici kişinin kendisidir. Kişiler arası iletişim en az iki kişinin duygu, düşünce ve sorunlarını birbiriyle paylaşmasından oluşur. Grup içi iletişimde ise grubu oluşturan bireylerin belirlenmiş rol ve statülere göre birbirleriyle iletişim kurması söz konudur. Kitle iletişimi ise mesajların televizyon, radyo, internet, gazete, kitap, dergi, sinema gibi iletişim araçları vasıtasıyla hedefe iletilmesini anlatır. İletişimi bıraktığ 1 etkiye göre olumlu ve olumsuz iletişim olarak da sınıflandırmak mümkündür. İletişim süresinde ve sonucunda kişiler memnun ve gereksinimler karşılanmış durumda ise olumlu iletişim, bunun aksi bir durum söz konusuysa olumsuz iletişim gerçekleşmiştir (Kaya, 2012'den aktaran; Yıldırım t.y., s. 7-8).

Kişiler arasındaki ilişki çeşitli nedenlerden dolayı bozulabileceğinden iletişimde etkililiği gerçekleştirmek bir amaç olmakla birlikte her zaman ulaşılabilecek bir sonuç değildir. Araştırmacılar olumsuz iletişimin gerçekleşmesine neden olan faktörleri genel olarak fiziksel ve teknik engeller, psikolojik ve sosyal engeller ile örgütsel engeller olarak kategorilere ayırmaktadırlar. Fiziksel ve teknik engeller mesaj, kanal ve araçlar, gürültü ve dil ile ilgili nedenlerden kaynaklanmaktadır. Psikolojik ve sosyal engellere neden olan unsurlar ise iletişim amacının belli olmaması, önyargılar, görüş ve algılama farklılıkları, tutum ve davranışlar, sosyo-kültürel farklılıklar ve sahip olunan bilgi düzeyidir. Örgütün büyüklüğ̈̈, fiziksel yapısı, geri besleme yetkisizliği, aşırı bilgi yüklemesi, statü farklılıkları, yönetim tarzı, hiyerarşi, rol ilişkileri, zaman baskısı gibi etmenler ise etkili ve sağlıklı iletişimi engelleyen örgütsel engellerdir (Elgünler-Fener, 2011, s. 35-38).

$\mathrm{Bu}$ engellerin ortadan kalkması için iletişim ortamlarında, statü farklılıkları minimize edilmeli, uygun bir fiziki mesafe kullanılmalı, önyargılar giderilmeli, herkes için aynı anlamı taşıyan sözcüklerin kullanılmasına özen göstermeli, sözcükler açık ve net olmalı, konuşmacılar etkin olarak dinlenmeli, geri bildirimde bulunulmalı, gürültü en aza indirilip sesiz ortamlar oluşturulmalı, güven ortamı oluşturulmalı, kişinin kapasitesini aşacak şekilde bilgi yüklenmemeli, iletişim doğru yer ve zamanda gerçekleşmelidir (Yazıcı ve Gündüz, 2010, s. 50-51).

Yetişkinler arasındaki iletişim kadar yetişkin-çocuk arasındaki iletişim de üzerinde durulması gereken konulardan biridir. Çocukla iletişimin temel amacı sağlıklı kişilik oluşturmaktır. Kişiliğin temelleri beş, altı yaşlarında atılır ve sonraki yıllarda ise bu temel üzerinde gelişme ve olgunlaşma olur. 
Ebeveyn ve öğretmenler gibi çocukla sürekli iletişim içinde bulunan insanlar çocuğa ve çocukluğa has özellikleri bilmelidirler. Çocuğu anlamak ve tanımak sağlıklı iletişim kurmanın koşuludur. Çocuklar büyüme, değişme ve gelişme dönemlerinde kendisini yetiştiren insanlardan ilgi ve sevgi dolu iletiler beklerler. Çocuklarla iletişimin temeli onları sevmekten ve onlara ilgi göstermekten geçer (Köknel, 2005, s. 257-260).

İletişim, insanların konuşmaları, akıl ve yaratıcılığını kullanarak bu olguyu geliştirmeleri sonucu insanlarla özdeşleşir duruma gelmiş olsa da yeryüzünde yaşayan tüm canlılar için geçerli olan ve bu yönüyle evrensel bir değer taşıyan geniş kapsamlı bir kavramdır. Doğumundan ölümüne kadar geniş bir iletişim ağı içinde olan insan yalnızca aile, arkadaş, iş yaşamında değil, toplumsal yaşamın her evresinde iletişimle iç içedir. İnsanoğlunun doğasında var olan ve bireyi yalnızlıktan, bilgisizlikten kurtaran; onu dışa dönük, yeniliklere açı, yorum yapma ve düşündüğünü ifade etme gücüne sahip bir konuma getiren iletişim bu özelliklerinden dolayı başarılı bireyler, sağlıklı toplumlar yaratmanın etkili araçlarından biri olarak düşünülmektedir (Gönenç, 2007, s. 87-89).

İletişim en eski kabilelerden en modern toplumlara kadar önemli bir ihtiyaç olarak görülmüş ve insanoğlu bu sosyal gereksinimin üstesinden gelmek için çeşitli araçlar geliştirmiş, yöntemler kullanmıştır. Görsel işitsel araçların olmadığı dönemlerde insanlar dini ritüeller, avlanma için yapılan törenler, eğlence amaçlı gösteriler gibi toplulukların bir araya geldiği kimi durumlarda kullanılmak üzere birtakım işaret, ses, sembol, dans ve kuklalardan yararlanmışlar ve bunun sonucu olarak da tiyatro sanatını ortaya koymuşlardır (Tarlakazan, 2018, s. 915).

Türkiye'de Batı tiyatrosunun benimsenmesinden önce etkin olan özgün ve geleneksel bir tiyatro anlayışı vardı. Köylünün yaşantısıyla yoğrulmuş olan köy tiyatrosuna karşın kentlerde daha doğrusu başkentte varlık gösteren ve daha çok İstanbul'a özgü olan halk tiyatrosu, geleneksel Türk tiyatrosunun iki önemli kaynağıydı. Meddah, çengi, köçek ve kuklanın yanı sıra Anadolu'da beğeniyle izlenen ve hâyali denilen kişiler tarafindan oynatılan Karagöz, halk tiyatrosu geleneğinin başlıca türüydü (And, 2014, s. 11-49).

Toplumu bilgilendirme işlevinin yanı sıra bilgiyi de toplumsal duruma getiren, farklı insan gruplarını, bunlar arasındaki ilişkileri ve ortak değerleri yansıtan Karagöz, hem eğlence hem de kültürlenme unsurudur (Anameriç, 2014, s. 360-361). Televizyonun olmadığ dönemlerde aile bireyleri ile komşular arasındaki muhabbetlerin önemli ögesi durumuna gelmiş olan gölge oyunu, evlenme, sünnet gibi özel törenlerin vazgeçilmez eğlencesi olmuştur. Bu bakımdan Karagöz, 16 ve 19. yüzyıllar arasında Osmanlının eğlence kültüründe önemli kaynaklarından biri olarak kabul edilir. 17. yüzyılda Evliya Çelebi Seyahatnamesi, Naima ve Abdi gibi yerli sanatçıların eserleri, 18 ve 19. yüzyıllarda Seyyid Vehbi, Haşmet, Kani, Sururi gibi şairlerin eserleri ile yabancı yazarların verdikleri bilgilerden hareketle ülkenin pek çok yerinde evlenme, doğum, sünnet gibi törenlerde, Ramazan'da kahvehanelerde, saray, konak ve evlerde Karagöz oynatıldığ kayıtlara bakıldığında sadece eğlence değil, aynı zamanda taşlama aracı olarak da kullanıldığı görülmektedir. Osmanlı sultanlarından Abdulaziz, devlet adamlarına göndermeler yaptığı gerekçesiyle bu sanattan hiciv ve yergiyi çıkarır. Karagöz'ün bu özelliği siyasi mizah dergileri ile gazetelerinde devam etmeye başlar (Çolakoğlu, 2006, s. 547).

Sınırsız bir özgürlüğün temsilcisi olarak sultandan başka herkesi taşlayan, vezirlere sataşan ve yabancı elçileri tedirgin eden söyleşmelerin bir diğer özelliği ise açık saçık oluşudur. Yerli kaynaklar bu konuda sessiz kalırken, yabancı kaynaklar gördükleri Karagöz’ün bu yönü üzerinde hemfikir olurlar. Geçen yüzyılda, Karagöz'ün siyasal taşlama ve açık saçıklığına karşı devletin ileri gelenlerinin tepki göstermesi, bir yandan da Batı tiyatrosunun Türkiye'ye girmesi Karagöz'ü sinırlayan bir tutumun gitgide gelişmesine neden olur (And, 2014, s. 44).

Kendisini ortaya koyan sanatçının amacı doğrultusunda yoğrulup renk ve şekil kazanan, kimi zaman eğlendiren kimi zaman da eleştirilerin odağında olan Karagöz oyununun ilk olarak nerede ve ne zaman ortaya çıktığı konusunda birbirinden farklı görüssler bulunmaktadır. Gölge oyununun doğuşuna yönelik olarak birçok görüşün mevcut olduğunu belirten Hınçer (1959) bu oyunların kökeninin Hint'e, Orta Asya'ya, Çin'e ve Japonya'ya kadar dayandığını belirtir. Çin'de ortaya çıkmasına ilişkin olarak kabul gören görüşler şöyledir: 
Çin'de doğuşu hakkında şu neticeye varılmıştır. Camın henüz keşfedilmediği zamanlarda Çin'de pencerelere kâğıt yapıştırılırmış. Işık yakıldığı zaman, içeride dolaşanların gölgeleri pencereye aksettiği için görülen hareketler hayal oyununun bulunmasına müncer olmuştur.

Grube'nin bir eserine yazdığı takdim yazısında, Lavfer bu hususu ispat etmiştir.İkinci görüşe istinaden Dr. Jakop, Çin gölgeleri, yani hayal ilk defa milattan evvel 121 tarihinde Vu adındaki Çin imparatoru zamanında ortaya çıkmıştır. İmparator Vu'ya ölen eşinin hasretini gidermek için bir oyuncu, bir perde arkasında onun hayalini göstermiştir demekte ve bu görüşü desteklemektedir (Hınçer, 1959).

Türk kültüründe yaklaşı 500 yıllık bir geçmişi olan gölge oyununun Türkiye'ye gelişi ile ilgili tartışmalar da henüz kesinlik kazanmış değildir (Tarlakazan, 2018, s. 916). Sakaoğlu'na göre "Türk gölge oyununun kökeni ile ilgili bilgilerin bir kısmı efsane ve rivayetlerden, bir kısmı da tarihsel belgelerden oluşur." (Düzgün, 2010, s. 26). Bu efsaneler arasında bir de oyunun mucidi olarak gösterilen Şeyh Küşteri bulunmaktadır (Düzgün, 2010, s. 26). Türkiye'de Karagöz oynatanların (hâyalilerin) rivayetlerine göre gölge oyunu 14. Asırda Şeyh Muhammed Küştâri (Küşter) tarafindan icat edilmiştir. Bursa Ulu Cami inşaatında çalışan Karagöz ve Hacivat isimli işçilerin hoş sohbetleri caminin tamamlanmasını geciktirdiği için Sultan Orhan öfkelenir ve ikisinin öldürülmesini ister. Aslen İranlı olan Küştâri verdiği karardan pişmanlık duyan sultanı teselli etmek için iki kahramanı tasvir ederek beyaz perdede yaşatmaya çalışmıştır (Hınçel, 1959).

İkinci rivayet ise belirttiği üzere Evliya Çelebi'nin kalemiyle bizlere ulaşır. Seyahatname'de anlatılanlara göre Efelioğlu Hacı Eyvad olarak bilinen Hacivat Mekke'den Bursa'ya gidip gelmekte ve Yorkça Halil olarak tanınmaktadır. Karagöz ise İstanbul tekfurunun seyisidir ve Sofyozlu Karagöz Bâli Çelebi olarak bilinmektedir. Karagöz, tekfur tarafından yılda bir kez Selçuklu topraklarına gönderildiğinde Hacivat ile buluşur ve onların söyleşmeleri gölge oyunu olarak oynatılır. Evliya Çelebi'nin yaşadığı çağdan 400 yıl öncesine dayandırarak anlattığı bilgilerin doğruluğunun sorgulanabilir olduğunu belirten And (1968), dönemin güvenilir kaynaklarından yola çıkarak bu oyunun Yavuz Sultan Selim döneminde Misır'dan getirildiğini ifade eder.

Televizyon, radyo, sinema gibi görsel iletişim araçlarının doğuşundan çok önce var olan başlarda insanlar1 eğlendirmek, daha sonra da günlük yaşam, eğitim, politika, siyasi görüş gibi pek çok ana konuyu işleyerek, iletişim kaynağı olan gölge oyunu (Tarlakazan, 2018, s. 915) Karagöz ve Hacivat arasındaki diyaloglardan oluşur. Buradaki diyaloglar bireyler arasındaki muhabbet veya problemsiz bir iletişim değil, bir tür engelli koşudur. İletişimin akışını sürekli kesen engellerin yol açtığı gerilim, kuklacının koşunun ritmini iyi ayarlaması ve engelleri çeşitlendirmesi seyirciyi ekrana bağlar. $\mathrm{Bu}$ bakımdan gölge oyununda dil önemli bir komedi alanıdır. Karagöz karakterine tanınan bu yapısal ayrıcalık gölge oyununun Karagöz ismiyle öne çıkmasını sağlamıştır. Hacivat sohbet etmek isteyen kişi durumundayken, Karagöz ise engel yaratan konumundadır. Karagöz'ün müdahaleleri ve cevapları birer iletişim engelidir (Mizrahi, 2009).

Günümüzde Karagöz sanatının yerini bilgisayar, dijital oyunlar, akıllı telefonlar gibi elektronik cihazlar almış, modern dünyanın insanı zamanının önemli bir kısmını ekranın karşısında geçirmeye başlamıştır. Sokakta oynanan oyunlardan, sosyal ilişkilerden uzaklaşmaktadırlar. Şenyer'in (2014) belirttiği gibi geniş kitlelerce pek bilinmese de Karagöz çocukların sosyal ilişkilerini güçlendiren, hayal kurma becerilerini geliştiren önemli bir eğitim aracıdır. Perdenin arkasına geçerek dijital bağımlılıktan bir an için uzaklaşan çocuklar bu oyun aracılığıyla kendilerini daha rahat ifade edecekleri için özgüven de kazanırlar. Nitekim gölge oyununun eğitimde kullanılmasına yönelik olarak yapılan akademik çalışmalar Karagöz metinlerinin kazanımların kavratılması boyutunda önemli birer materyal olduğunu göstermektedir.

Mete ve Dağ (2019, s. 345) 5. Sınıf ders kitabında saygı ifade eden kalıpların bulunma düzeyini araştırmışlar ve doğrudan nezaket anlatan kullanımlara sadece Karagöz metninde yer verildiğini ortaya koymuşlardır. Karagöz oyunlarında bulunan karakter ve diyalogların Türk toplumunu en iyi yansıtan ürünlerden biri olduğunu dile getiren Yılmaz ve Taşkın (2014, s. 287) araştırmasında canlandırma gerektirmeyen gölge oyununun yabancılara Türkçe öğretmede ve Türk kültürünü aktarmada önemli bir eğitim araç olabileceğini belirtmişlerdir. 
Demir ve Özdemir (2013, s. 57-78) gölge oyununun değer aktarımına yönelik katkısını ortaya koymayı amaçladığı araştırmalarında İlköğretim Sosyal Bilgiler Dersi (4.-8. Sınıflar) Öğretim Programı ve Kılavuzu'nda verilen değerlerden hareketle bir form hazırlamış ve bu formu Türkçe dersinde gölge oyununu kullanarak öğrencilere uygulamışlardır. "Değerleri İnceleme Formu" adil olma, bilimsellik, sorumluluk, hoşgörü gibi toplam 18 değerden oluşmaktadır. Araştırmanın sonunda Karagöz metinlerinin değer aktarımı ve öğretimi konusunda zengin bir kaynak olduğu tespit edilmiştir. Karagöz metinlerinin öğretime olan katkısını Türkçe ve Sosyal Bilgiler dersi belirli dersler ile sinırlamamak gerekir.

Öçal ve Doğan $(2015$, s. 2) 6. sınıf fen ve teknoloji dersi "Dolaşım Sistemi” konusunda, KaragözHacivat diyaloglarının kullanımının öğrencilerin akademik başarılarına etkililiğini incelemek ve derse uygulanabilirliğini ortaya koymak amacıyla bir ortaokulda okuyan 26 öğrenciyi kontrol, 24 öğrenciyi ise deney grubu olarak belirlemişlerdir. Araştırma verilerinin çözümü için öğrencilere "Ön Bilgi Testi” ve Başarı Testi uygulanmış, ayrıca uygulamalar süresince öğrencilerden günlük tutmaları istenerek onların derste Karagöz ve Hacivat diyaloglarının kullanımına yönelik görüşleri tespit edilmeye çalışılmıştır. Araştırma sonucunda deney grubu öğrencilerin başarı puanlarının daha yüksek olduğu ve öğrencilerin dersten keyif aldığ 1 görülmüştür. Araştırmacılar bu tespitten hareketle Türk gölge oyunu metinlerinin fen ve teknoloji dersi için de etkili bir materyal olduğu sonucuna ulaşmışlardır.

Günümüzde ise kitaplarda tek tük kendine yer bulan Karagöz oyununun erdemlerin ve tiyatro türünün öğretiminde kullanıldığı görülmektedir. UNESCO tarafından İnsanlığın Somut Olmayan Kültürel Mirası Temsilî Listesine alınan Karagöz yalnızca eski Ramazan günlerinin yâd edilmesinde veya geleneksel sanatların konu edinildiği bir platformda değil, eğitim sürecinin her kademesinde ele alınmalıdır. Unutulmamalıdır ki "Karagöz-Hacivat; müziğiyle, kostümleriyle, mimarisiyle yüksek bir sanat ruhu yaratmakta oldukça etkili bir araçtır. Bu özelliklerinden dolayı; Karagöz-Hacivat sadece edebî zevki geliştirmek ya da gülmece için değil ciddi bir eğitim materyali olarak da kullanılabilir." (Öçal ve Doğan, 2015, s. 2)

\section{AMAÇ}

$\mathrm{Bu}$ çalışmanın amacı, Karagöz metinlerini iletişim boyutuyla ele almak ve metinde geçen mizah unsurlarını tespit etmektir. Bu amaç çerçevesinde aşağıdaki sorulara yanıt aranmıştır:

1. Karagöz metinlerinde iletişimi sağlayan unsurlar nelerdir?

2. Karagöz metinlerinde iletişimsizliğe neden olan unsurlar nelerdir?

3. Karagöz metinlerinde yer alan mizah unsurları nelerdir?

4. Karagöz metinlerinde yer alan mizah unsurları hangi nedenlerden kaynaklanmaktadır?

5. Karagöz metinlerinde yer alan mizah unsurlarının iletişime olan etkisi nedir?

6. Türkçe ders kitaplarında Karagöz metinlerine yer verilme oranı nedir?

7. Türkçe ders kitaplarında Karagöz metinleri hangi tür/türlerde okuyucuya sunulmuştur?

8. Türkçe ders kitaplarında Karagöz metinleri hangi temalarla ilişkilendirilmiştir?

9. Türkçe ders kitaplarında Karagöz metinleri hangi dil becerileriyle ilişkilendirilmiştir?

\section{YÖNTEM}

Türkçe ders kitaplarında yer alan Karagöz ile Hacivat metinlerini iletişim boyutuyla ele almayı ve bu metinlerde yer alan mizah unsurlarını tespit etmeyi amaçlayan bu araştırma nitel araştırma yöntemlerinden olup doküman incelemesi modelindedir. Araştırmanın evreni ders kitaplarıyla, örneklemi ise 2018-2019 Eğitim-Öğretim Y1lı içinde Ortaokul ve İmam Hatip Ortaokulunda okutulması ön görülen Türkçe ders kitaplarıyla sınırlıdır. Araştırmanın verileri 5. Sınıflar için 1 (MEB Yayınları), 6. Sınıflar için 2 (MEB ve Eksen Yayınları), 7. Sınıflar için 3 (MEB, MEB ve Dersdestek Yayınları), 8. Sınıflar için 1 (MEB Yayınları) kitap olmak üzere toplam 7 ders kitabının incelenmesinden elde edilmiş ve betimsel analizle çözümlenmiştir. Betimsel yaklaşım verilerin belirlenen temalara göre özetlenmesine ve yorumlanmasına dayanır (Yıldırım ve Şimşek, 2013, s. 256). İncelenen ders kitaplarında Karagöz ve Hacivat oyununa yönelik metinlerin varlığı araştıılıış, bu metinler türleri bakımından sınıflandırılmış ve içerik yönünden irdelenmiştir. Ayrıca metinlerin dil 
becerileriyle olan ilişkisi ile hangi tema ve alt temanın altında yer aldığı üzerinde durulmuştur. İletişimle ilgili bölümlerin altı çizilmiş, verilen mesajların iletişimin hangi boyutuna hizmet ettiği dile getirilmiş ve mizah unsurları vurgulanmıştır. Mizah unsurlarının söze mi yoksa harekete mi dayandığı örnek metinlerden yapılan alıntılarla desteklenmiştir.

\section{BULGULAR}

Karagöz metinlerinin türleri, dil becerileri, tema ve alt tema bakımından dağılımları ile iletişim konusuna yönelik tespitler tablolarla; söze ve harekete dayalı mizah unsurları ise metinlerden alınan pasajlarla desteklenmiştir.

Tablo 1. Ders kitaplarında Karagöz metinlerinin bulunma durumu

\begin{tabular}{|c|c|c|}
\cline { 2 - 3 } \multicolumn{1}{c|}{ Toplam Kitap Sayısı } & Frekans & Yüzdelik \\
\hline Karagöz Metinlerinin Yer Aldığı Kitap Sayısı & $\mathbf{7}$ & $\mathbf{\% 1 0 0}$ \\
\hline Karagöz Metinlerinin Yer Almadığı Kitap Sayısı & 1 & $\% 86$ \\
\hline
\end{tabular}

Tablo 1'de 2018-2019 Eğitim Öğretim yılı içinde okutulması ön görülen 7 kitaptan yalnızca birinde Karagöz metnine yer verilmediği; incelenen kitapların \%86'sında Karagöz ile ilgili bilgilere yer verildiği görülmektedir.

Tablo 2. Karagöz metinlerinin türleri bakımından dağılımı

\begin{tabular}{|c|c|c|c|}
\hline \multirow{2}{*}{ Düzey } & Ders Kitapları & Metnin Adı & Metnin Türü \\
\hline \multirow{2}{*}{ 5. Sınıf } & MEB Yayınları & Karagöz ile Hacivat-İncelik & Tiyatro \\
\hline \multirow{2}{*}{ 6. Sınıf } & MEB Yayınları & Evet Efendim & Tiyatro \\
\cline { 2 - 4 } & Eksen Yayınları & Bilmece & Tiyatro \\
\hline \multirow{2}{*}{ 7. Sınıf } & MEB Yayınları 1 (Kır vd. 2018) & Karagöz Nedir? & Makale \\
\cline { 2 - 4 } & MEB Yayınları 2 (Akgül vd. 2018) & Dostluk & Tiyatro \\
\cline { 2 - 4 } & Dersdestek Yayınları & Bilmece & Tiyatro \\
\hline 8. Sınıf & MEB Yayınları & - & - \\
\hline
\end{tabular}

Tablo 2'de belirtildiği üzere ana metinlerin 5 tanesi tiyatro, bir tanesi ise makale türündedir. İncelenen kitaplarda Karagöz metinlerinin ağırlıklı olarak tiyatro türünde öğrenciye sunulduğu görülmektedir.

Tablo 3. Karagöz metinlerinin dil becerileri bakımından dă̆ılımı

\begin{tabular}{|c|c|c|c|c|}
\hline Düzey & Ders kitapları & Metnin Adı & $\begin{array}{c}\text { Karagöz } \\
\text { Metinlerinin } \\
\text { İlişkilendirildiği } \\
\text { Dil Becerileri }\end{array}$ & $\begin{array}{c}\text { Karagöz } \\
\text { Metinlerinin } \\
\text { İlişkilendirilmediği } \\
\text { Dil Becerileri }\end{array}$ \\
\hline \multirow{2}{*}{ 5. sınıf } & MEB Yayınları & $\begin{array}{c}\text { Karagöz ile } \\
\text { Hacivat-İncelik }\end{array}$ & $\begin{array}{c}\text { Konuşma, } \\
\text { Dinleme, } \\
\text { Okuma, Yazma }\end{array}$ & - \\
\hline \multirow{2}{*}{ 6. sınıf } & MEB Yayınları & Evet Efendim & $\begin{array}{c}\text { Okuma, } \\
\text { Konuşma, } \\
\text { Dinleme }\end{array}$ & Yazma \\
\cline { 2 - 5 } & Eksen Yayınları & Bilmece & $\begin{array}{c}\text { Konuşma, } \\
\text { Okuma, Dinleme }\end{array}$ & Yazma \\
\hline \multirow{2}{*}{ 7. sinıf } & $\begin{array}{c}\text { MEB Yayınları 1 (Kır- } \\
\text { vd. 2018) }\end{array}$ & Karagöz Nedir? & $\begin{array}{c}\text { Dinleme, } \\
\text { Okuma, } \\
\text { Konuşma, } \\
\text { Yazma }\end{array}$ & - \\
\cline { 2 - 6 } & $\begin{array}{c}\text { MEB Yayınları 2 (Akgül } \\
\text { vd. 2018) }\end{array}$ & Dostluk & $\begin{array}{c}\text { Okuma, } \\
\text { Konuşma, } \\
\text { Dinleme }\end{array}$ & Yazma \\
\hline
\end{tabular}




\begin{tabular}{|c|c|c|c|c|}
\hline & Dersdestek Yayınları & Bilmece & $\begin{array}{c}\text { Dinleme, } \\
\text { Okuma, } \\
\text { Konuşma, } \\
\text { Yazma }\end{array}$ & - \\
\hline 8. sinıf & MEB Yayınları & - & - & - \\
\hline
\end{tabular}

Tablo 3’te görüldüğ̈̈ gibi 5, 6 ve 7. sınıf ders kitaplarında Karagöz'le ile ilgili metinlere yer verilmiş ve bunlar temel dil becerileri ile desteklenmiştir. Yalnızca 8. Sınıf ders kitabında konuyla ilgili örnek metne rastlanılmamıştır. Ayrıca üç metinde konunun dört temel dil beceriyle ilişkilendirildiği; geri kalan metinlerde ise yazma becerisi dışında bütün dil becerilerine yer verildiği tespit edilmiştir. Karagöz metnini yazma becerisiyle desteklemeyen kitaplar; 6. sınıf ders kitapları ile (MEB Yayınları, Eksen Yayınları), 7. sınıf MEB Yayınları 2 (Akgül vd., 2018) kitabıdır.

Tablo 4. Karagöz metinlerinin tema ve alt tema bakımından dağılımı

\begin{tabular}{|c|c|c|c|c|}
\hline Düzey & Ders Kitapları & Metnin Adı & $\begin{array}{l}\text { Metnin } \\
\text { Teması }\end{array}$ & $\begin{array}{l}\text { Metnin Alt } \\
\text { Teması }\end{array}$ \\
\hline $\begin{array}{c}5 . \\
\text { Sinif }\end{array}$ & MEB Yayınları & $\begin{array}{c}\text { Karagöz ile } \\
\text { Hacivat-İncelik }\end{array}$ & Erdemler & $\begin{array}{l}\text { Görgü Kuralları } \\
\text { ve Nezaket }\end{array}$ \\
\hline \multirow{2}{*}{$\begin{array}{c}6 . \\
\text { Sinif }\end{array}$} & MEB Yayınları & Evet Efendim & $\begin{array}{l}\text { Birey ve } \\
\text { Toplum }\end{array}$ & $\begin{array}{l}\text { İletişimde } \\
\text { Nezaket }\end{array}$ \\
\hline & Eksen Yayınları & Bilmece & $\begin{array}{l}\text { Çocuk } \\
\text { Dünyası }\end{array}$ & Bilmeceler \\
\hline \multirow{3}{*}{$\begin{array}{c}7 . \\
\text { Sinif }\end{array}$} & $\begin{array}{c}\text { MEB Yayınları } 1 \text { (Kır vd. } \\
\text { 2018) }\end{array}$ & Karagöz Nedir? & $\begin{array}{c}\text { Millî̀ } \\
\text { Kültürümüz }\end{array}$ & Gölge Oyunu \\
\hline & $\begin{array}{l}\text { MEB Yayınları } 2 \text { (Akgül vd. } \\
\text { 2018) }\end{array}$ & Dostluk & Erdemler & Dostluk \\
\hline & Dersdestek Yayınları & Bilmece & $\begin{array}{c}\text { Millî } \\
\text { Kültürümüz }\end{array}$ & Seyirlik Oyunlar \\
\hline $\begin{array}{c}8 . \\
\text { Sinıf }\end{array}$ & MEB Yayınları & - & - & - \\
\hline
\end{tabular}

Tablo 4'te belirtildiği üzere Karagöz metinleri 4 farklı tema ile ilişkilendirilmiştir. İkişer metin millî kültümüz ve erdemler; birer metin ise birey ve toplum; çocuk dünyası ile ilgilidir. İncelenen kitaplarda yer verilen alt temalar ise; görgü ve nezaket kuralları, iletişimde nezaket, bilmeceler, gölge oyunu, dostluk ve seyirlik oyunlardır. Alt temaları, görgü ve nezaket kuralları, seyirlik oyunlar, bilmeceler ve dostluk olmak üzere 4 başlıkta toplamak mümkündür. 
Tablo 5. Karagöz metinlerinde iletişim

\begin{tabular}{|c|c|c|c|}
\hline 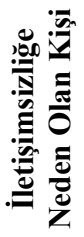 & İletişim Sorunları & 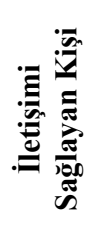 & İletişimi Sağlayan Unsurlar \\
\hline 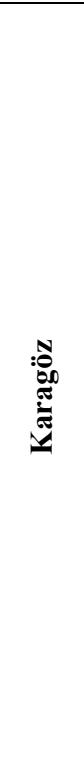 & $\begin{array}{c}\text { Yalnızca konuşmayı sevme } \\
\text { Konuşanın sözünü kesme } \\
\text { Düşünmeden konuşma } \\
\text { Sözü yanlış duyma } \\
\text { Sözü yanlış anlama } \\
\text { Zayıf bir sözcük hazinesine sahip olma } \\
\text { Dilin inceliklerini bilmeme } \\
\text { Sözcükler ve cümleler arasında mantıksal } \\
\text { ilişki kuramama } \\
\text { Görgü ve nezaket kurallarını bilmeme } \\
\text { Eleştiriye açıı olmama } \\
\text { Sinirli olma } \\
\text { Kırıcı olma } \\
\text { Önyargılı olma } \\
\text { Sabit fikirli olma } \\
\text { Hırslı olma } \\
\text { Yanlışı sürdürmede 1srarcı olma } \\
\text { Yersiz davranışlarda bulunma } \\
\text { Anlayıştan yoksun olma } \\
\text { İnce bir düşünce gücüne sahip olamama } \\
\text { Olay ve sözlerden basit çıarımlara ulaşma }\end{array}$ & 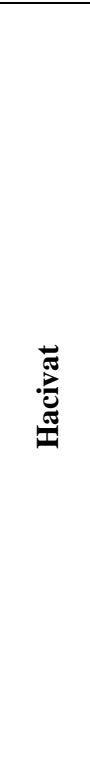 & $\begin{array}{c}\text { Konuşmayı ve dinlemeyi sevme } \\
\text { Dinleyene saygı duyma } \\
\text { İletişime açık olma } \\
\text { Sorunlara ve kişilere çözüm odaklı yaklaşma } \\
\text { Zengin bir sözcük hazinesine sahip olma } \\
\text { Dilin inceliklerini bilme } \\
\text { Hoşgörülü olma } \\
\text { Sabırlı olma } \\
\text { Sağduyulu olma } \\
\text { Yanlışı düzeltmede ve doğruyu öğretmede } \\
\text { kararlı olma } \\
\text { Eleştiriye açık olma } \\
\text { Bilgili olma } \\
\text { Öfkesine hâkim olabilme } \\
\text { Anlayışlı olma } \\
\text { İnce bir düşünce gücüne sahip olma } \\
\text { Olay ve sözlerden derin çıkarıllara ulaşma } \\
\text { Öğretmeyi sevme }\end{array}$ \\
\hline
\end{tabular}

Tablo 5'te görüldügü gibi iletişimsizliğe neden olan kişi Karagöz, iletişim sorunları ise Karagöz'ün söylediği sözler ya da neden olduğu durumlardır: Yalnızca konuşmayı sevme, Konuşanın sözünü kesme, Düşünmeden konuşma, Sözü yanlış duyma vb.

Gölge oyununda iletişimi sürdüren kişi Hacivat; iletişimi sağlayıcı unsurlar ise yine Hacivat'ın kişiliğinden, tutum ve davranışlarından kaynaklanan durumlardır: Konuşmayı ve dinlemeyi sevme, Dinleyene saygı duyma, İletişime açık olma, Sorunlara ve kişilere çözüm odaklı yaklaşma vb.

Karagöz'ün söylediği sözlerden ya da neden olduğu durumlardan dolayı iletişimi engellediği, Hacivat'in ise devam ettiren kişi olduğu görülmektedir. Karagöz'ün sahip olduğu özellikler ve temsil ettiği karakter iletişimin önünde bir engel olmakla birlikte gölge oyununa mizah değeri katmaktadır. Karagöz'ün sözü yanlış anlaması, dilin inceliklerini bilmemesi, nezaket kurallarına yoksun olması gibi daha pek çok özelliği metni eğlenceli hale getirerek okuyucu ve izleyiciyi güldürmektedir. Normal koşullarda insanı sevimsizleștiren bu tür durumların Karagöz'e yönelik sempatiye dönüşmesinin nedeni onun alık ve doğal tavırlarıdır. Sözcük ve tavırların eğlenceli bir forma dönüştüğü Karagöz metinlerinde mizaha dayalı unsurları şunlardır:

\section{Karagöz Metinlerinde Söze Dayalı Mizah Unsurları}

Karagöz metinlerinde söze dayalı mizah unsurlarının Karagöz'ün özelliklerinden kaynaklandığı görülmektedir. Karagöz'ün görgü ve nezaket kurallarını doğru bilmemesi, bilgisizliği, ukalalığı, mantık yürütememesi, eleştiriye açık olmaması, fazla iddialı oluşu, sözü yanlış duyması, basit düşünmesi, geçimsiz ve aksi tavırları, sözcükler arasında mantıksal ilişki kuramaması, olaylar arasında mantıksal ilişki kuramaması, alaycı sözler kullanması, Karagöz'ün sık sık sözcük tekrarına düşmesi, amiyane tabirler kullanması, sözünü esirgememesi metni komik hale getirmektedir. Dağ’a göre (2006, s. 32-33) Karagöz'ün hazır cevaplılığı, ters durumlar oluşturması, yanlışı çok doğal ve uygun şartlarda vermesi, aynı oyunda benzer harf değişikliğiyle yapılmış olan gülmece konuşmalarla devam etmesi metni gülünç duruma getiren dilsel tekniklerdir.

Örnek: Aşağıda Karagöz'ün görgü ve nezaket kurallarını doğru bilmemesi anlatılmaktadır: 
Hacivat: Eksik olma Karagöz'üm! Sonra efendim, alışveriş yapmak için sokağa çıktım. Bir de baktım ki köşe başında iki kişi kavga ediyorlar. Ayırayım diye aralarına girdim. O sırada polisler gelmez mi? Beni de kavgacılardan sanıp karakola götürdüler. Oradan da doğru hapishaneye...

Karagöz: Oh oh! Çok sevindim! Güle güle oturunuz, içinden hiç çıkmayınız!

Hacivat: Aman kardeş, sen ne diyorsun? Beni hapse attılar. Karagöz: İyi ya oh oh! Çok sevindim!

Güle güle.. (Ağın Haykır vd. 2018, s. 80)

Bu metinde Karagöz'ün olumlu bir durum için sözlenen kalıp bir ifadeyi -güle güle oturunuzanlamını düşünmeden olumsuz bir durum için de kullanması, metni eğlenceli hale getirmiştir. Aşağıdaki bölümde ise Karagöz'ün bilgiç ve ukala söylemler içine girdiği görülmektedir:

"Hacivat: Yaa!

Karagöz: Yaa! Ne sandın? Bilmece demek, ben demek; ben demek, bilmece demek. Söyle bilmeceni, al cevabını.” (Şekerci, 2018, s. 118)

\section{Karagöz Metinlerinde Harekete Dayalı Mizah Unsurları}

İncelenen metinlerde harekete dayalı mizah unsurlarının yine Karagöz'ün özelliklerinden kaynaklandığı görülmektedir. Karagöz'ün yok yere sinirlenip Hacivat'1 dövmesi, Hacivat'ı dövdükten sonra sahneden çekip gitmesi, Hacivat'1n sözünü kesmesi, Düşünmeden konuşan Karagöz'ün Hacivat'ı kızdırması, Karagöz'ün alık ve doğal tavırları okuyucuyu güldürmektedir.

Örnek: Aşağıda Karagöz’ün yok yere sinirlenip Hacivat'ı dövmesi anlatılmaktadır.

Hacivat: Vay Karagöz'üm, benim iki gözüm, merhaba!

Karagöz: Hoş geldin, suda pişmiş balkabağı! (Tokat atar.)

Hacivat: Aman Karagöz'üm, gelir gelmez bu tokadın sebebi nedir?

Karagöz: Bizim bekçinin ne poturu var ne de cübbesi. (Tokat atar.)

Hacivat: Yazıklar olsun sana Karagöz! Adam olamamışsın!

Karagöz: Ona ya Rabbi şükür!

Hacivat: Ne gibi?

Karagöz: Ya sen oldun mu ki? (Tokat atar.) (Ceylan vd. 2018, s. 242).

Karagöz'ün Hacivat'ın söylediği her sözü anlamaya çalışmak bir yana tokatla karşıllık vermesi metne hareket katmaktadır. Atılan tokada karşılık Hacivat'tan büyük bir tepki beklenirken, Hacivat'in bu durumu sakin ve olağan karşılaması gölge oyunu izleyicisine de bir komedi izlediği hissini vermektedir. Ünlü'ye (2007, s. 29-40) göre dil anlaşmazlıklarının ve vuruşmaların yan sıra ve şiddete gülmek geleneksel Türk tiyatrosuna mizah sağlamaktadır. Kişilerin, perdenin, olayların iç gerçeği, bütün bunların bir oyun olduğu vurgusuyla tekrar tekrar bozulmakta, günlük yaşamın yanı sıra onun taklidi olabilecek oyun da böylelikle ters yüz edilmektedir. Mizahın bu başkaldırıcı özelliği günlük yaşamın kurallarla ve hiyerarşik yapıyla belirlenmiş olan sabit yapısını parçalamakta ve kişinin kendinde gördüğ̈̈ fakat bilinçaltına attı̆g durumları gülme yoluyla dışarı atmasına yardımcı olmaktadir.

\section{SONUÇ VE ÖNERILER}

Anadolu topraklarında uzun yıllar boyunca ilgi odağı olan Karagöz, metni yazan ve seslendiren sanatçıların amaçlarına bağlı olarak kimi zaman eğlence, kimi zaman siyasi taşlama, kimi zaman da toplumsal konuları mizansen bir üslupla sözcülügünü yapan bir rol üstlenmiştir. Bu çalışmada Karagöz metinleri iletişim yönünden ele alınmış ve bu metinlerde yer alan mizah unsurları tespit edilmiştir.

2018-2019 Eğitim Öğretim Yı1ı içinde okutulması ön görülen 7 kitaptan yalnızca birinde Karagöz metnine yer verilmediği; incelenen kitapların \%86'sında Karagöz ile ilgili bilgilere yer verildiği görülmektedir. Ana metinlerin 5 tanesi tiyatro, bir tanesi makale türündedir. İncelenen kitaplarda Karagöz metinlerinin ağırlıklı olarak tiyatro türünde okuyucuya sunulduğu tespit edilmiştir. Dil 
becerileriyle ilişkilendirilme bakımından 3 metinde konunun dört temel dil becerisiyle ilişkilendirildiği; geri kalan metinler (3) de ise yazma becerisi dışında bütün dil becerilerine yer verildiği tespit edilmiştir. Karagöz metinleri 4 farklı tema ile ilişkilendirilmiştir. İkişer metin millî kültümüz ve erdemler; birer metin ise birey ve toplum ile çocuk dünyası ile ilgilidir. Alt temaları, görgü ve nezaket kuralları, seyirlik oyunlar, bilmeceler ve dostluk olmak üzere 4 başlıkta toplamak mümkündür. Karagöz metinlerinin ilişkili olduğu tema ve alt temalar gölge oyununun Türkçenin ve Türk kültürünün aktarılmasında (Yılmaz ve Taşkın, 2014), saygı ve nezaket kurallarının öğretiminde (Mete ve Dağ, 2019), değerlerin kavratılmasında (Demir ve Özdemir, 2013) önemli bir araç olduğunu ifade eden araştırmaları desteklemektedir.

Gölge oyununda iletişimsizliğe neden olan kişi Karagöz, iletişim sorunları ise Karagöz'ün söylediği sözler ya da neden olduğu durumlardır. Gölge oyununda iletişimi sürdüren kişi Hacivat; iletişimi sağlayıcı unsurlar ise yine Hacivat'ın kişiliğinden, tutum ve davranışlarından kaynaklanan durumlardır. Karagöz metinlerinde söze ve harekete dayalı mizah unsurlarının Karagöz'ün özelliklerinden kaynaklandığı görülmektedir.

Sonuç olarak; incelenen metinlerde Karagöz'ün söylediği sözlerin, sergilediği davranışların iletişimsizliğin önünde güçlü birer engel olduğu, bu engelin, Hacivat'ın sahip olduğu yapıcı özellikler aracılığıyla aşıldığı, iletişimin zor şartlarda bile sürdürülebileceğini gösteren Karagöz-Hacivat metinlerinin okuyucuyu güldüren, eğlendiren birer mizah unsuruna dönüştüğü görülmektedir. $\mathrm{Bu}$ tespitlerden hareketle aşağıdaki önerilerde bulunmak mümkündür:

1. Değerlerin veya güncel konuların işlendiği yeni metinlerle Karagöz ve Hacivat'ın yaşadığımız çağa getirilmesi sağlanmalıdır. Nitekim Şişman $(2009$, s. 613) da çalışmasında Karagöz metinlerinin modernize edilmesinin ve bugünün gereksinimlerine yanit verecek şekilde hazırlanmasının ona olan ilgiyi daha artırmakla beraber onu yarınlara taşıyacak köprüler kurmasına zemin hazırlayacağını belirtir.

2. Türkçe ders kitaplarında en az bir metin gölge oyunu ile ilgili olmalıdır.

3. Kitaplarda yer alan metinler sınıf içinde canlandırılmalıdır.

4. Karagöz metinleri bütün dil becerileriyle ilişkilendirilmelidir. Örneğin yardımlaşma konulu bir gölge oyunu yazdırılabilir ya da eleştirel konuşma yöntemiyle öğrencilerden Karagöz'ün/Hacivat'ın kişilik özellikleri konusunda bir sunum yapmaları istenebilir.

5. Karagöz ve Hacivat'1 göze görünür kılmak ve öğrencilerin el becerilerini geliştirmek için kâğıttan kuklalar yaptırılabilir. Resim sanatıyla desteklenen tiyatro metni böylelikle daha etkili bir niteliğe sahip olacaktır.

\section{Bilgilendirme / Acknowledgement:}

1- Bu çalışma, 14-17 Şubat 2019 tarihleri arasında Yalova'da düzenlenen (UBAK-2019) 4. Uluslararası Bilimsel Araştırmalar Kongresi'nde sunulan bildirinin tam metin hâlidir.

2- Makalede doküman analizi yapıldığından etik kurulu izni ve/veya yasal/özel izin alınmasını gerektiren bir durum yoktur.

3- Bu makalede araştırma ve yayın etiğine uyulmuştur.

\section{KAYNAKÇA}

Ağın Haykır H., Kaplan H., Kıryar, A., Tarakçı, R. ve Üstün E. (2018). Ortaokul ve imam hatip ortaokulu Türkçe ders kitabı 5. Ankara: MEB Yayınları.

Akgül, A., Demirer, N, Gürcan, E., Karadaş, D, Karahan, İ. ve Uysal, A. (2018). Ortaokul ve imam hatip ortaokulu Türkçe 7 ders kitabı. Ankara: MEB Yayınları.

Anameriç, H. (2014). Bilginin toplumsallaşmasında bir bilgi kaynağı olarak gölge tiyatrosu: Karagöz ve Hacivat. Uluslararası Kültürel Mirasın ve Kültürel Bellek Kurumlarının Yönetimi Kongresi (17-20 Eylül 2014). Urla. 1-18. Osmanlı Arşivi Daire Başkanlığı, İstanbul: 360-375. 
And, M. (1968). Karagöz üzerindeki bilgilere yeni katkılar. Türk Dili Dergisi, 207. 1 Ocak 2019 tarihinde https://www.karagoz.net/yeni katkilar metin and.htm adresinden erişildi.

And, M. (2014). Başlangıcından 1983'e Türk tiyatro tarihi. İstanbul: İletişim Yayınları.

Cengiz, M. N. (2019). İletișim nedir? Sözlü ve sözsüz iletişim. 16.05.2020 tarihinde https://www.iienstitu.com/blog/iletisim-nedir-sozlu-ve-sozsuz-iletisim adresinden erişildi.

Ceylan, S., Duru, K., Erkek, G. ve Pastutmaz M. (2018). Ortaokul ve imam hatip ortaokulu Türkçe ders kitabı 6. Ankara: MEB Yayınları.

Çolakoğlu, G. (2006). Gelenekten beslenen Karagöz. Folklor/Edebiyat, 12(46), 543-554.

Dağ, O. (2006). Hacivat ile Karagöz piyeslerinde komik ve uyumsuz dilsel öğeler. Yayımlanmamış yüksek lisans tezi, Atatürk Üniversitesi, Erzurum.

Demir, T. ve Özdemir, B. (2013). Türkçe eğitiminde Karagöz / gölge oyunları ile değer öğretimi. Değerler Ĕgitimi Dergisi, 11(25), 57-89.

Düzgün, D. (2010). Türk gölge oyunu karagözde İstanbul hayatı. A. Ü. Türkiyat Araştırmaları Enstitüsü Dergisi [TAED], 43, 25-33.

Elgünler, T. Ç. ve Fener, T. Ç. (2011). İletişimin kalitesini etkileyen engeller ve bu engellerin giderilmesi. The Turkish Online Journal Of Design., Art And Communication-Tojac, 1(1), 35-39.

Gönenç, E. Ö. (2007). İletişimin tarihsel süreci. İletişim Fakültesi Dergisi, 28, 87-102.

Hınçer, İ. (1959). Gölge oyununun doğuşu. Türk Folklor Araştırmaları Dergisi, 5(119), 1931-1932.

Kaya, A. (2012). İletişime giriş: temel kavramlar ve süreçler. (4. Baskı). (Ed. Alim Kaya) Kişilerarası ilişkiler ve etkili iletişim içinde. Ankara: Pegem-A Yayınları.

Kaya, B. (2018). Ortaokul ve imam hatip ortaokulu Türkçe 7 ders kitabı. Ankara: Dersdestek Yayınc1lik.

Kır, T., Kırman, E. ve Yağız, S. (2018). Ortaokul ve imam hatip ortaokulu Türkçe ders kitabı 7. Ankara: MEB Yayınları.

Köknel, Ö. (2005). İnsanı anlamak. İstanbul: Altın Kitaplar Yayınevi.

Mete, F. ve Dă̆, M. (2019). 5. sınıf Türkçe ders kitabında saygı ifade kalıpları. Değerler Ĕ̈itimi Dergisi, 17(38), 333-355.

Mete, G., Karaslan, M., Kaya, Y., Ozan, Ș. ve Özdemir, D. (2018). Ortaokul ve imam hatip ortaokulu Türkçe ders kitabı 8. Ankara: MEB Yayınları.

Mizrahi, D. (2009). Osmanlı'da Karagöz oyunları. Toplumsal Tarih Dergisi, 181, 48-55.

Öçal, E. ve Doğan, A. (2015). Karagöz-Hacivat (Türk gölge oyunu) diyaloglarıyla fen eğitimi. Kafkas Üniversitesi, e - Kafkas Ë̆itim Araştırmaları Dergisi, 2(2), 1-11.

Şekerci, Y. (2018). 6. sınıf ortaokul Türkçe ders kitabı. Ankara: Eksen Yayınları.

Şenyer, E. (2014). Çocuklarda televizyon bağımlılı̆̆ı 14.04.2020 tarihinde https://www.karagoz.net/cocuklarda_televizyon_bagimliligi.htm adresinden erişildi.

Şişman, B. (2009). Türk gölge oyununun konularının ve suretlerinin güncelleştirilmesi. Uluslararası Sosyal Araştırmalar Dergisi, 2(6), 610-616.

Tarlakazan, B. E. (2018). Türk gölge oyunu 'Karagöz'de doğaüstü tasvir ve semboller. Anemon Muş Alparslan Üniversitesi Sosyal Bilimler Dergisi, 6(6), 915-923.

Ünlü, A. (2007). Şiddete gülmek: geleneksel Türk tiyatrosunda şiddet ve mizah. Tiyatro Araştırmaları Dergisi, 24, 27-41. 
Yazıcı, Ö. ve Gündüz, Y. (2010). Etkili eğitim denetiminde yaşanan iletişim engelleri ve bu engelleri aşma yolları. Kuramsal Eğitimbilim, 3(2), 37-52.

Yıldırım, A. ve Şimşek, H. (2013). Sosyal bilimlerde nitel araştırma yöntemleri. Ankara: Seçkin Yayınc1lik.

Yıldırım, İ. (t.y.). İletişime giriş. 16.05.2020 tarihinde https://docplayer.biz.tr/113395925-Iletisimprof-dr-ibrahim-yildirim.html adresinden erişildi.

Yılmaz, F. ve Taşkın, M. (2014). Hacivat Karagöz oyunları ile Türkçenin yabancı dil olarak öğretimi ve kültür aktarımı. Akademik Sosyal Araştırmalar Dergisi, 5, 270-288. 